CIRJE-F-969

\title{
Abenomics: Why Was It So Successful in Changing Market Expectations?
}

\author{
Shin-ichi Fukuda \\ The University of Tokyo
}

March 2015

CIRJE Discussion Papers can be downloaded without charge from:

http://www.cirje.e.u-tokyo.ac.jp/research/03research02dp.html

Discussion Papers are a series of manuscripts in their draft form. They are not intended for circulation or distribution except as indicated by the author. For that reason Discussion Papers may not be reproduced or distributed without the written consent of the author. 


\title{
Abenomics: Why was it so successful in changing market expectations?*
}

\author{
Shin-ichi Fukuda (University of Tokyo) ${ }^{* *}$
}

\begin{abstract}
'Abenomics' refers to a new unconventional economic policy regime in Japan since late 2012. It consists of the three arrows: unconventional monetary policy (the first arrow), expansionary fiscal policy (the second arrow), and economic growth strategies to encourage private investment (the third arrow). After the new regime started, both the stock market and the foreign exchange market reacted very favorably. The purpose of this paper is to investigate why the markets reacted to the new regime so favorably. Unlike orthodox arguments, we focus on asymmetric behavior between local and foreign investors after December 2012. We show that under the new regime, foreign investors were aggressive in purchasing Japanese stocks and in selling the Japanese yen, while local investors were not. By using high frequency intra-daily data, both structural break tests and regression analysis show that various news shocks had more significant impacts on the stock prices and exchange rates in nighttime than in daytime even if they were revealed in daytime. Noting that local investors tend to trade in daytime, while foreign investors tend to trade in nighttime, this implies that the dramatic market responses to the new regime happened only in time zones when foreign investors were active. However, the asymmetry might have been less significant after the market crash on May 23, 2013.
\end{abstract}

Key words: unconventional policy, structural break, stock price, exchange rate, intra-daily data

\footnotetext{
* An earlier version of this paper was presented at PRI-ADBI conference on August 282013 , AEEF conference on October 28-29 2013, and TCER conference on March 7 2014. I would like to thank Koichi Hamada, Masahiro Kawai, Etsuro Shioji, and other conference participants for their helpful comments. This research was supported by the Ministry of Education, Science, Sports and Culture, Grant-in-Aid for Scientific Research (B) 26285044 and JSPS Core-to-Core Program, B. Asia-Africa Science Platforms, JSPS Grant-in-Aid for Challenging Exploratory Research.

** Correspondence address: Shin-ichi FUKUDA, Faculty of Economics, University of Tokyo, 7-3-1 Hongo Bunkyo-ku Tokyo 113-0033 JAPAN. E-mail: sfukuda@e.u-tokyo.ac.jp, Fax: 81-3-5841-5521.
} 


\section{Introduction}

'Abenomics' refers to the new economic policy regime advocated by the Prime Minister of Japan, Shinzo Abe. It is a set of policy measures meant to resolve Japan's macroeconomic problems. It consists of the three arrows: unconventional monetary policy (the first arrow), expansionary fiscal policy (the second arrow), and economic growth strategies to encourage private investment (the third arrow). Through the three arrows, the Japanese government tried to revive its economy through implementing bold economic policies that will pull its economy out of prolonged deflation, depreciate Japanese yen, and induce CPI inflation rate of $2 \%$ per year.

Both the stock market and the foreign exchange market reacted to the new policy regime very favorably. Figure 1 depicts daily data of the Japanese stock price index (Nikkei 225, 3pm in Tokyo) and the yen-dollar exchange rates (5pm in Tokyo) from January 2012 to October 2014. Before Mr. Abe came to power in December 2012, the stock price index stagnated around 9,000 yen. However, it rose up to 10,688 yen at the beginning of January 2013 and exceeded 15,000 yen on May 15, 2013. Abenomics was also successful in achieving depreciation of the yen, which had been stagnating around 80 yen per dollar in 2012. The yen-dollar rates depreciated to 88 yen at the beginning of January 2013 and to 102 yen on May 15, 2013. Both stock price increase and yen's depreciation did not persist after the market crash on May 23, 2013. ${ }^{1}$ However, the improved market environments can be the first step toward a much brighter future in the Japanese economy.

The purpose of this paper is to investigate why the markets reacted to the new policy regime so favorably. Unlike orthodox arguments, we focus on asymmetric behavior between local and foreign investors under the new regime. We show that under the new regime, foreign investors were aggressive in purchasing Japanese stocks and in selling the Japanese yen, while local investors were not. One may argue that the markets reacted favorably because they expected strong recovery of Japanese macro fundamentals under the new regime. It is true that after the dramatic changes of the stock prices and the Japanese yen, Japanese macro fundamentals also improved substantially. In particular, consumer spending pushed first quarter economic growth up 3.5 percent annually and remained strong in the second quarter of 2013. However, these improvements seem to be the results of the favorable market responses rather than the causes of them. In fact, various surveys clearly show that the improved confidences of Japanese

1 On October 31st 2014, the Bank of Japan announced expansion of the Quantitative and Qualitative Monetary Easing (QQE), which lead to further stock price increase and yen's depreciation. However, the impact of this event is out of scope of this paper. 
consumers and enterprises lagged behind the favorable market responses. More importantly, even in the markets, the responses to the new regime were very different between local and foreign investors. That is, various data suggest that after Mr. Abe came to power, only foreign investors were aggressive in purchasing Japanese stocks and in selling Japanese yen. This implies that there have been highly heterogeneous views on Abenomics in the markets. In the following analysis, we explore whether the heterogeneity was a main source of the favorable market responses to Abenomics.

To capture heterogeneity, we particularly focus on intra-daily data which splits the market data into daytime changes and nighttime changes and explore whether there was conspicuous asymmetry across the time zones under Abenomics. In the analysis, we first apply structural break tests to examine whether stock prices and yen-dollar rates had structural break(s) in daytime and in nighttime. We then investigate whether news shocks under Abenomics were responsible to the structural break(s) by regression analysis. We draw inferences about the impact of various news shocks on the behavior of stock prices and exchange rates. The regression results suggest that before the market crash on May 23, 2013, various news shocks about Abenomics had more significant impacts on the stock prices and exchange rates in Japan nighttime than in Japan daytime even if the shocks were revealed in Japan daytime. Noting that local investors tend to trade in daytime, while foreign investors tend to trade in nighttime, this implies that the dramatic market responses under the new regime happened only in time zones when foreign investors were active. However, the asymmetry might have disappeared after the market crash on May 23, 2013.

Even among economists, foreign economists tended to be favorable to Abenomics. For example, in his column in New York Times, Krugman (2013) suggested that Japan had a prolonged slump mainly because it's hard getting policy makers to accept the need for bold action. He then praised Abenomics stating that "Mr. Abe has thumbed his nose at orthodoxy, with excellent results". IMF (2013) also wrote a favorable country report to Abenomics stating that "Japan's near-term economic prospects have improved with the adoption of vigorous macroeconomic policies combining fiscal stimulus with unprecedented monetary easing”. In contrast, not a few Japanese economists were still conservative in evaluating Abenomics. For example, Ueda (2013) argued that "a non-negligible portion of the asset price response seems based on investors' excess optimism concerning the effectiveness of non-conventional monetary policy". At this stage, it is still too soon to evaluate which view is correct. However, the data clearly shows that at least before May 23, 2013, it was foreign investors' responses that 
improved the market sentiments under the new regime. Given the fact, we may conclude that the initial impacts of Abenomics might not have been so successful unless foreign investors reacted to the new policy regime favorably.

In literature of financial economics, the efficient-market hypothesis (EMH) asserts that financial markets are "informationally efficient". In consequence of this, one cannot consistently achieve returns in excess of average market returns on a risk-adjusted basis, given the information available at the time the investment is made. The semi-strong-form EMH claims that prices which reflect all publicly available information instantly change to reflect new public information. To the extent that EMH holds, the market should have had much larger responses in daytime than in nighttime because most of the news about Abenomics were revealed in daytime. Out finding, however, suggested the opposite. That is, the market responded more in nighttime than in daytime. This suggests that highly heterogeneous views persisted between daytime and nighttime investors at least at the first stage of Abenomics.

There are a large number of papers which explored unconventional policies in Japan (see, for example, Fujiwara (2006), Honda et al. (2007), Oda and Nagahata (2008), Ueda (2012), Koeda (2013), Nakazono and Ueda, (2013), and Honda (2014)) ${ }^{2}$. In particular, Rogers et al. (2014) examined the effects of unconventional monetary policy by central banks in advanced countries on bond yields, stock prices and exchange rates by using intradaily data. But few explored them by using high frequency data with market-specific features. In investigating market-specific features by intra-daily data, our analysis has motivations that are similar to those in Ito and Roley (1987), Tsutsui and Hirayama (2010), and Fukuda (2012). These studies pointed out that there were different market responses in different time zones. However, no previous studies explored market-specific features under Abenomics. Investigating what happened under the new regime in Japan is worthwhile to be noted because Abenomics had dramatic impacts on the markets.

The paper proceeds as follows. Sections 2 and 3 investigate who responded to Abenomics and when the markets responded respectively. After testing structural changes in intra-daily data in section 4, the regression analysis in section 5 shows that various news shocks had more significant impacts on the stock prices and exchange rates in Japan nighttime. Section 6 summarizes our main results and refers to their implications.

2 There are a huge number of studies that explored the effects of unconventional monetary policy by central banks in advanced countries. See, for example, Krishnamurthy and Vissing-Jorgensen (2011), Rosa (2012), Gambacorta et al. (2014), and Lambert and Ueda (2014) fore recent contributions. 


\section{Who Responded to Abenomics Favorably?}

After Mr. Abe came to power, both the stock market and the foreign exchange market reacted to the new policy regime very favorably. However, the reactions were asymmetric between local and foreign investors. In this section, we provide some basic statistics that may support such a view. When exploring who responded to Abenomics favorably, we can observe conspicuous asymmetric behavior between local and foreign investors when exploring who purchased Japanese stocks after November 2012.

Figure 2 reports which type of investors purchased Japanese stocks based on Trading Value by Investor Type TSE 1st Section by Tokyo Stock Exchange, Inc. The types of investors are local institutions, local individuals, local securities companies, and foreigners. It depicts their amount of net purchases (that is, purchases minus sales) in brokerage trading from January 2012 to October 2014. Before Mr. Abe came to power, we could not see distinct behavioral difference across the investors. However, net purchases of foreigners jumped up to 150 billion yen in December 2012 and remained taking large positive value until the end of 2013. In contrast, net purchases of local institutions and local individuals took large negative values during the same period. The distinct behavior was especially conspicuous in April 2013 when new Governor of the Bank of Japan (BOJ), Haruhiko Kuroda, announced radical quantitative easing (QQE) to achieve inflation targeting at a $2 \%$ annual rate in two years.

Table 1 summarizes how the amount of net purchases by each type of investors was correlated with the change in the stock price index (Nikkei 225) and with that in the yen-dollar exchange rate. The weekly data from January 2012 to October 2014 is obtained from Trading Value by Investor Type Tokyo and Nagoya by Tokyo Stock Exchange. To allow structural breaks, we calculated the correlation not only for the whole sample but also for the subsamples (Jan. 2012 - Oct. 2012, Nov. 2012 - Dec. 2013, Dec. 2012 - May 2013, and Jan. 2014 - Oct. 2014). The correlation was in marked contrast between that by foreign investors and that by local investors. In case of foreign investors, the amount of net purchases had been positively correlated with the changes in the stock price index and the yen-dollar rates. This was true even before Abenomics started. But after Abenomics started, the positive correlation increased significantly. The correlation was especially high from December 2012 to May 2012 when the stock prices increased dramatically and the yen-dollar rate depreciated substantially In contrast, in case of local institutions and individuals, the amount of net purchases had been positively 
correlated with the change in the stock price index and the yen-dollar rate until the end of 2013. This was especially for local individuals whose negative correlation was more substantial than local institutions. The results suggest that foreign investors played a leading role in improving the market sentiments in Abenomics especially before the market crash on May 23, 2013.

Figure 3 reports regional shares of foreign investors based on Investments in Listed Stocks by Nonresidential Investors (by region) by Tokyo Stock Exchange, Inc.. It depicts the amount of net purchases in brokerage trading from January 2012 to October 2014 in each region: North America, Europe, Asia, and others. Before Mr. Abe came to power, the amount of net purchases was limited in any region. However, in North America, Europe, and Asia, the amount increased dramatically in December 2012 and kept taking large values until the end of 2013. Among the three regions, net purchases of European investors were rather volatile reflecting unstable European economies. In contrast, net purchases of North American investors remained stable until the end of 2013. However, net purchases in North America and Asia started to decline since the beginning of 2014 .

\section{When Did the Markets Respond Favorably?}

(1) Japan Daytime and Nighttime

In the last section, we presented a view that both the stock market and the foreign exchange market reacted to the new policy regime favorably because Abenomics changed market sentiments of foreign investors. In this section, we reexamine this view through exploring when the markets responded favorably. Exploring when the Japanese stock price increased and the yen-dollar rate depreciated, we can observe conspicuous asymmetry across the time zones after November in 2012.

Figure 4 summarizes time zones we use for Japan daytime and nighttime in the following analysis. In case of Nikkei 225 Futures which is futures trading of NIKKEI 225 index, trade takes place not only in Osaka but also in Chicago. We define the price change from Osaka close (3:15pm in Osaka) to Chicago close (3:15pm in Chicago, 6:15am in Osaka) as the price change in Japan nighttime. We then compare it with that in Japan daytime which is defined as the price change from Chicago close to Osaka close. To check its robustness, we also use the changes of Nikkei 225 (spot trading). In case of Nikkei 225, trade takes place only from 9am to 3pm in Japan time. But potential orders in Japan nighttime are priced in the first few minutes after 9am in Japan time. We thus regard the price change from 3pm in Tokyo to 9:15am in Tokyo in the 
following business day as the price change in Japan nighttime and compare it with that in Japan daytime (from 9:15am in Tokyo to 3pm in Tokyo).

In contrast with the stock markets, the foreign exchange market is open 24 hours a day. We thus define the change of the yen-dollar rate from 9am in Tokyo to 5pm in Tokyo as the exchange rate change in Japan daytime and that from 5pm in Tokyo to 9am in Tokyo in the following business day as the exchange rate change in Japan nighttime. To check its robustness, we also report the change from $5 \mathrm{pm}$ in Tokyo to $5 \mathrm{pm}$ in New York as an alternative measure for that in Japan nighttime.

\section{(2) The Stock Prices}

Table 2 summarizes basic statistics (average and standard deviation) of the daily change of the two stock price indexes, Nikkei 225 Futures and Nikkei 225 (spot index), in the two time zones. It reports those from January 2012 to October 2014 and those for its sub-periods. It is noteworthy that in both Nikkei 225 Futures and Nikkei 225, the average was negative in daytime but positive in nighttime for the full sample period. This implies that the two stock price indexes tended to increase in Japan nighttime and to decrease in Japan daytime. The feature essentially held even before November 15 in 2012 and after May 23 in 2013. But the difference between the two time zones was rather moderate for the sub-periods, although the standard deviation was larger for the latter sub-period. In contrast, the average difference between the two time zones became conspicuous between November 15 in 2012 and May 22 in 2013 when the stock price indexes increased dramatically. This implies that the dramatic increases in the stock prices under Abenomics occurred in Japan nighttime rather than in Japan daytime.

Figure 5 depicts accumulated change of Nikkei 225 Futures and that of Nikkei 225 both in Japan daytime and in Japan nighttime since the beginning of November 2012 to the end of October 2014. It normalizes the value to be zero on October 31 in 2012. The accumulated daytime change of Nikkei 225 Futures was negligible before May 22 in 2013, while it turned to be negative after May 23 in 2013. In contrast, the accumulated nighttime change amounted to 6365 yen on May 23 in 2013 and remained high after that, although it became volatile after late May in 2013. The result is essentially the same in the accumulated change of Nikkei 225. In nighttime, it increased dramatically after Mid November in 2012. In contrast, in daytime, its change was negligible, although it was positive from April 4 in 2013 to May 20 in 2013, while it remained negative after that. 
Theoretically, both local and foreign investors can trade in any markets in the world. But it is natural to suppose that Japanese local investors tend to trade in Japan daytime, while foreign investors tend to trade in Japan nighttime. The above result thus suggests that the dramatic stock market boom under Abenomics happened only in time zones when foreign investors were active.

(3) The yen-dollar exchange rates

Table 3 summarizes basic statistics (average and standard deviation) of the daily change of the yen-dollar exchange rate from January 2012 to October 2014. It reports its change in Japan daytime (from 9am in Tokyo to 5pm in Tokyo) and that in Japan nighttime (from 5pm in Tokyo to 9am in Tokyo in the following business day). To check its robustness, it also reports the change in an alternative Japan nighttime (from $5 \mathrm{pm}$ in Tokyo to $5 \mathrm{pm}$ in New York). It is easy to see that for the full sample period and for sub-periods until December 2013, the average was negative in daytime but positive in nighttime. ${ }^{3}$ This implies that the Japanese yen tended to appreciate in daytime and depreciate in nighttime. Even before November 2012, the Japanese yen depreciated in nighttime and to appreciate in daytime. But the yen's depreciation in nighttime was moderate before Abenomics. In contrast, between November 15 in 2012 and May 22 in 2013, the Japanese yen depreciated dramatically in nighttime, while it kept having modest appreciation in daytime. Its standard deviation also became large in both time zones for the sub-sample periods.

When we use the change in the alternative nighttime (from $5 \mathrm{pm}$ in Tokyo to $7 \mathrm{am}$ in Tokyo in the following business day), the yen's depreciation in nighttime was less dramatic for the full-sample period. This implies that the yen tended to depreciate from 7am to 9am in Tokyo time when the Sydney market started its transactions. But even for the alternative nighttime measure, we can still observe the yen's depreciation in nighttime. In particular, for the sub-period between November 15 in 2012 and May 22 in 2013, we can confirm that the yen depreciated dramatically only in the alternative nighttime. This implies that the dramatic yen's depreciation under Abenomics occurred in the alternative nighttime, that is, from 5pm in Tokyo to $7 \mathrm{am}$ in Tokyo in the following business day.

Figure 6 shows accumulated change of the yen-dollar rate in Japan daytime and that in Japan nighttime since the beginning of November in 2012. It normalizes the value to be zero on

3 The daytime yen also started to depreciate in 2014 but its changes were modest. 
October 31 in 2012. The change of the yen-dollar rates was negligible in daytime, although it had some marginal appreciation since January 10 in 2013. In contrast, the accumulated depreciation of the yen-dollar rate in nighttime was substantial. It amounted to 23 yen/dollar on May 13 in 2013 and kept its depreciated level after that. The essential feature remains true for the alternative nighttime measure. To the extent that Japanese local investors tend to trade in Japan daytime and that foreign investors tend to trade in Japan nighttime, this suggests that the dramatic depreciation of the yen under Abenomics happened only in time zones when foreign investors were active.

\section{Tests of Structural Changes in Intra-daily Data}

In the last section, we showed evidence that both the stock price and the yen-dollar rate had asymmetric responses under Abenomics depending on the time zone. The asymmetric responses may explain why the markets reacted to the announced new policy regime so favorably. In the following sections, we will examine the validity of this conjecture through formal econometric tests based on intra-daily data. This section first applies structural break tests to explore when the stock price and the yen-dollar rate in daytime and in nighttime had structural break(s).

Unlike the Chow test which tests for regime change at a priori known date, we apply two alternative tests where the break date is unknown. One is the Quandt-Andrews test which modified the Chow framework to consider the F-statistic with the largest value over all possible break dates. Andrews (1993) derived the limiting distribution of the related test statistics. Assuming $15 \%$ trimming, we use them to identify a single unknown break date and to test the significant level of the structural break. The other is the Bai-Perron test which extended the Quandt-Andrews framework by allowing for multiple unknown breakpoints. Bai and Perron (2003) provided theoretical and computational results. Assuming 15\% trimming and allowing error distributions to differ across breaks, we use them to explore multiple unknown break dates and their significance.

To test structural break(s), we estimate the following equations for daytime and nighttime changes in the Nikkei Futures and in the yen-dollar exchange rate respectively.

(1) $\Delta \ln \left(D S_{\mathrm{t}}\right)=$ const. $+\mathrm{a}_{1} \Delta \ln \left(D S_{\mathrm{t}-1}\right)+\mathrm{b}_{1} \Delta \ln \left(N S_{\mathrm{t}-1}\right)+\Sigma_{\mathrm{j}} \mathrm{d}_{1, j} \Delta \ln \left(X_{\mathrm{t}}^{\mathrm{t}}\right)+\mathrm{e}_{1, \mathrm{j}} \Delta Y_{\mathrm{t}}$,

(2) $\Delta \ln \left(N S_{\mathrm{t}}\right)=$ const. $+\mathrm{a}_{2} \Delta \ln \left(D S_{\mathrm{t}}\right)+\mathrm{b}_{2} \Delta \ln \left(N S_{\mathrm{t}-1}\right)+\sum_{\mathrm{j}} \mathrm{d}_{2, \mathrm{j}} \Delta \ln \left(X_{\mathrm{t}}^{j}\right)+\mathrm{e}_{2, \mathrm{j}} \Delta Y_{\mathrm{t}}$,

(3) $\Delta \ln \left(D E_{\mathrm{t}}\right)=$ const. $+\mathrm{a}_{3} \Delta \ln \left(D E_{\mathrm{t}-1}\right)+\mathrm{b}_{3} \Delta \ln \left(N E_{\mathrm{t}-1}\right)+\Sigma_{\mathrm{j}} \mathrm{d}_{3, \mathrm{j}} \Delta \ln \left(X_{\mathrm{t}}^{\mathrm{j}}\right)+\mathrm{e}_{3, \mathrm{j}} Y_{\mathrm{t}}+\Sigma_{\mathrm{j}} \mathrm{f}_{3, \mathrm{j}} \Delta \ln \left(Z_{\mathrm{t}}^{j}\right)$, 
(4)

$\Delta \ln \left(N E_{\mathrm{t}}\right)=$ const. $+\mathrm{a}_{4} \Delta \ln \left(D E_{\mathrm{t}}\right)+\mathrm{b}_{4} \Delta \ln \left(N E_{\mathrm{t}-1}\right)+\Sigma_{\mathrm{j}} \mathrm{d}_{4, \mathrm{j}} \Delta \ln \left(X_{\mathrm{t}}^{\mathrm{t}}\right)+\mathrm{e}_{4, \mathrm{j}} Y_{\mathrm{t}}+\sum_{\mathrm{j}} \mathrm{f}_{4, \mathrm{j}} \Delta \ln \left(Z_{\mathrm{t}}^{\mathrm{j}}\right)$,

where $\Delta \ln \left(D S_{\mathrm{t}}\right) \equiv \operatorname{logged}$ difference of the daytime stock price index, $\Delta \ln \left(N S_{\mathrm{t}}\right) \equiv \operatorname{logged}$ difference of the nighttime stock price index, $\Delta \ln \left(D E_{\mathrm{t}}\right) \equiv \operatorname{logged}$ difference of the daytime yen-dollar rate, and $\Delta \ln \left(N E_{\mathrm{t}}\right) \equiv \operatorname{logged}$ difference of the nighttime yen-dollar rate.

Equations (1) - (4) suggest that the changes in the Nikkei 225 Futures and in the yen-dollar exchange rate depend on the constant term, their lag dependent variables, and exogenous variables. Three types of exogenous variables, that is, $\Delta \ln \left(X_{\mathrm{t}}^{j}\right), \Delta Y_{\mathrm{t}}$, and $\Delta \ln \left(Z_{\mathrm{t}}^{\mathrm{j}}\right)$, are included to capture the effects of external shocks including policy shocks outside Japan.

The first type of exogenous variable $\Delta \ln \left(X_{t}^{j}\right)$ is a daily return in the stock price index in the United States, Europe, and Asia. Specifically, we use the latest return of NY Dow, that of FT100 in London, and that of Hang Seng index in Hong Kong for $\Delta \ln \left(X_{\mathrm{t}}^{j}\right)$. The second type of exogenous variable $\Delta Y_{\mathrm{t}}$ is a daily change of US long-term interest rate. Specifically, we use the latest yield change of 5-year US government bond. Although US short-term interest rate hit its zero bound, the 5-year US government bond yield was still positive in our sample period. Thus, it is likely that $\Delta Y_{\mathrm{t}}$ reflects the change of the US monetary policy in our sample period. ${ }^{4}$ The third type of exogenous variable $\Delta \ln \left(Z_{t}^{j}\right)$, which is included only in equations (3) and (4), is a daily growth rate of the euro-dollar exchange rate. Specifically, we use the latest change of the euro-dollar exchange rate in Japan daytime and that in Japan nighttime. We included $\Delta \ln \left(Z_{t}^{j}\right)$ to capture exogenous shocks that are specific to the foreign exchange market outside Japan.

The estimation period is from the beginning of January in 2011 to the end of October in 2014. We use the Nikkei 225 Futures from 6:15am to 3:15pm or the Nikkei 225 from 9:15am to $3 \mathrm{pm}$ for the daytime stock price index, and the Nikkei 225 Futures from 3:15pm to 6:15am in the following business day or the Nikkei 225 from 9am to 9:15am in the following business day for the nighttime stock price index. We also use the yen-dollar rate from 9am to $5 \mathrm{pm}$ in Tokyo for the daytime yen-dollar rate, and the yen-dollar rate from 5pm to 9am in Tokyo in the following business day or the yen-dollar rate from $5 \mathrm{pm}$ in Tokyo to $5 \mathrm{pm}$ in New York for the nighttime yen-dollar rate.

Table 4 summarizes the results of the Quandt-Andrews test. In equations (2) and (4) which explored determinants of nighttime change, its LR and Wald F-statistic detected a structural

${ }_{4}^{4}$ Our sample is the period when FRB started to mention tapering of QE3. In particular, Bernanke's testimony to Congress (known as "taper tantrum") on May 22, 2013 had large spillover effects on the rest of the world. 
break at $1 \%$ significant level soon after Abe was elected to the Prime Minister of Japan on December 26. 2012. In equation (2), the detected break date in its nighttime change was December 31, 2012 for Nikkei 225 Futures and January 3, 2013 for Nikkei 225. In equation (4), it was December 28, 2012 for both of the two nighttime exchange rate changes. This implies that nighttime investors, who are likely to be foreign investors, changed their behavior at the very beginning of Abenomics when specific policy schemes had not yet been announced.

Even in equations (1) and (3) which explored determinants of daytime change, its LR and Wald F-statistic detected a structural break at 1\% significant level for Nikkei 225 Futures and for the daytime exchange rate change. But the detected break date was January 24, 2013 for Nikkei 225 Futures and was February 1, 2013 for the daytime exchange rate change, both of which suggest that a structural change occurred about one month after Abenomics started. Moreover, its LR and Wald F-statistic could detect no significant structural break for Nikkei 225 (spot price) in equations (1) and (3). Noting that a series of policy schemes were announced in January 2013, this suggests that daytime investors, who are likely to be local investors, made marginal change of their behavior only after specific features of Abenomics were revealed.

Table 5 summarizes the results of the Bai-Perron test. Except for daytime Nikkei 225 Futures and Nikkei 225 (spot price), their scaled F-statistic suggests that there were more than one significant structural break. But in all cases, the test static for the null of 0 vs. 1 detected the exactly the same break date as that in the Quandt-Andrews test. Moreover, the other detected dates were, if any, either before Abenomics or after the market crash in late May 2013. Thus, even if we allow multiple structural breaks, we still find that Abenomics changed the behavior of nighttime investors before specific policy schemes were announced, while it changed the behavior of daytime investors only after a series of policy schemes were announced in January 2013.

\section{Estimation Based on Intra-daily Data}

In the last section, we implemented structural break tests and found that the structural break dates were asymmetric across daytime and nighttime investors. In this section, we test the existence of asymmetric responses in intra-daily data by using a structural break dummy and news dummies. Specifically, based on a structural break dummy and four types of news shocks, we modify equations (1) - (4) and estimate the following explanatory equations: 
(5)

$$
\begin{aligned}
\Delta \ln \left(D S_{\mathrm{t}}\right)=\text { const. } & +D_{1}+\mathrm{a}_{1}\left(1+D_{1}\right) \Delta \ln \left(D S_{\mathrm{t}-1}\right)+\mathrm{b}_{1}\left(1+D_{1}\right) \Delta \ln \left(N S_{\mathrm{t}-1}\right) \\
& +\Sigma_{\mathrm{j}} \mathrm{d}_{1, \mathrm{j}}\left(1+D_{1}\right) \Delta \ln \left(X_{\mathrm{t}}^{j}\right)+\mathrm{e}_{1, \mathrm{j}}\left(1+D_{1}\right) \Delta Y_{\mathrm{t}} \\
& +\Sigma_{\mathrm{k}} \alpha_{1, \mathrm{k}} D 1 k_{\mathrm{t}}+\Sigma_{\mathrm{k}} \beta_{1, \mathrm{k}} D 2 k_{\mathrm{t}}+\sum_{\mathrm{k}} \gamma_{1, \mathrm{k}} D 3 k_{\mathrm{t}}+\sum_{\mathrm{k}} \delta_{1, \mathrm{k}} D 4 k_{\mathrm{t}},
\end{aligned}
$$

(6) $\quad \Delta \ln \left(N S_{\mathrm{t}}\right)=$ const. $+D_{2}+\mathrm{a}_{2} \Delta \ln \left(D S_{\mathrm{t}}\right)+\mathrm{b}_{2} \Delta \ln \left(N S_{\mathrm{t}-1}\right)+\Sigma_{\mathrm{j}} \mathrm{d}_{2, \mathrm{j}} \Delta \ln \left(X_{\mathrm{t}}^{\mathrm{j}}\right)+\mathrm{e}_{2, \mathrm{j}} \Delta Y_{\mathrm{t}}$

$$
+\sum_{\mathrm{k}} \alpha_{2, \mathrm{k}} D 1 k_{\mathrm{t}}+\sum_{\mathrm{k}} \beta_{2, \mathrm{k}} D 2 k_{\mathrm{t}}+\sum_{\mathrm{k}} \gamma_{2, \mathrm{k}} D 3 k_{\mathrm{t}}+\sum_{\mathrm{k}} \delta_{2, \mathrm{k}} D 4 k_{\mathrm{t}},
$$

(7) $\quad \Delta \ln \left(D E_{\mathrm{t}}\right)=$ const. $+D_{3}+\mathrm{a}_{3} \Delta \ln \left(D E_{\mathrm{t}-1}\right)+\mathrm{b}_{3} \Delta \ln \left(N E_{\mathrm{t}-1}\right)$

$$
\begin{aligned}
& +\Sigma_{\mathrm{j}} \mathrm{d}_{3, \mathrm{j}} \Delta \ln \left(X_{\mathrm{t}}^{j}\right)+\mathrm{e}_{3, \mathrm{j}} Y_{\mathrm{t}}+\Sigma_{\mathrm{j}} \mathrm{f}_{3, \mathrm{j}} \Delta \ln \left(Z_{\mathrm{t}}^{\mathrm{j}}\right) \\
& +\sum_{\mathrm{k}} \alpha_{3, \mathrm{k}} D 1 k_{\mathrm{t}}+\sum_{\mathrm{k}} \beta_{3, \mathrm{k}} D 2 k_{\mathrm{t}}+\sum_{\mathrm{k}} \gamma_{3, \mathrm{k}} D 3 k_{\mathrm{t}}+\Sigma_{\mathrm{k}} \delta_{3, \mathrm{k}} D 4 k_{\mathrm{t}},
\end{aligned}
$$

(8) $\quad \Delta \ln \left(N E_{\mathrm{t}}\right)=$ const. $+D_{4}+\mathrm{a}_{4} \Delta \ln \left(D E_{\mathrm{t}}\right)+\mathrm{b}_{4} \Delta \ln \left(N E_{\mathrm{t}-1}\right)$

$$
\begin{aligned}
& +\Sigma_{\mathrm{j}} \mathrm{d}_{4, \mathrm{j}} \Delta \ln \left(X_{\mathrm{t}}^{\mathrm{j}}\right)+\mathrm{e}_{4, \mathrm{j}} Y_{\mathrm{t}}+\Sigma_{\mathrm{j}} \mathrm{f}_{4, \mathrm{j}} \Delta \ln \left(Z_{\mathrm{t}}^{\mathrm{j}}\right) \\
& +\Sigma_{\mathrm{k}} \alpha_{4, \mathrm{k}} D 1 k_{\mathrm{t}}+\Sigma_{\mathrm{k}} \beta_{4, \mathrm{k}} D 2 k_{\mathrm{t}}+\Sigma_{\mathrm{k}} \gamma_{4, \mathrm{k}} D 3 k_{\mathrm{t}}+\Sigma_{\mathrm{k}} \delta_{4, \mathrm{k}} D 4 k_{\mathrm{t}} .
\end{aligned}
$$

The first and second lines of each equation examine how the structural break in the Quandt-Andrews test changed the determinants of the stock price and exchange rate growth in daytime and in nighttime. In the analysis, we consider a structural break dummy $D_{1}$ for $\Delta \ln \left(D S_{\mathrm{t}}\right)$, $D_{2}$ for $\Delta \ln \left(N S_{\mathrm{t}}\right), D_{3}$ for $\Delta \ln \left(D E_{\mathrm{t}}\right)$, and $D_{4}$ for $\Delta \ln \left(N E_{\mathrm{t}}\right)$. Each dummy takes one after the structural break in the Quandt-Andrews test and zero otherwise. We included each dummy not only for the constant term but also for the coefficient dummies.

The third line of each equation examines how various news shocks affected the the stock price and exchange rate growth in each time zone. In the analysis, we consider four types of news: news on monetary policy $(D 1 k)$, news on fiscal policy $(D 2 k)$, news on Abe's growth strategies $(D 3 k)$, and news on the elections which led the LDP (Abe's party) to the dominant party in the lower and the upper houses of parliament $(D 4 k)$. The list of each type of news shocks was summarized in Table 6. For $D 1 k^{\prime}$ ' and $D 4 k^{\prime}$, we include a dummy variable which takes one only on the event day and zero otherwise. For $D 2 k$ 's and $D 3 k$ 's, we include a dummy variable which takes one on the three consequent business days on and before the event day (that is, $T, T-1$, and $T-2$ where $T$ is the event day) and zero otherwise. The latter allows for the fact that news on fiscal policy and on Abe's growth strategies tended to be partially revealed before the formal announcement.

Except for D101 (that is, Abe's announcement to adopt unlimited monetary expansion), news dummies on monetary policy are those for each BOJ's "Statement on Monetary Policy" after December 2012. After preliminary regressions, we included them only when they were statistically significant at least in one of the four equations. Among thirteen dummies on 
monetary policy, D101, 102, D103, and D104 are dummies when Shirakawa was BOJ Governor, while the other $D 1 k^{\prime}$ s are those after Kuroda became BOJ Governor. In particular, D105 is the dummy for Governor Kuroda's first "Statement on Monetary Policy" which introduced the "Quantitative and Qualitative Monetary Easing (QQE)" and committed to achieve 2\% inflation target in 2 years. Since the effect of QQE on the markets was very large, we also included its lagged dummy D105(-1) which takes one on the day after the Kuroda's first statement and zero otherwise. D113 is the dummy for the BOJ's announcement on the expansion of QQE in October 2014.

The news dummies on fiscal policy consist of five dummies. D21, D22, and D23 are those for announcements on the supplementary budget for fiscal 2012, while D24 is for announcement on the supplementary budget for fiscal 2013. The news dummies on Abe's growth strategies consist of two dummies. D31 is a dummy for Abe Cabinet's announcement on "Japan Revitalization Strategy - JAPAN is BACK -" in June 2013. On the same day, Abe also announced "Basic Policies for Economic and Fiscal Management and Reform - Ending Deflation and Revitalizing the Economy -". D31 is a dummy for Abe Cabinet's announcement on the revised "Japan Revitalization Strategy" in June 2014.

The news dummies on elections consist of four dummies. D41 is a dummy for the day when the late Prime Minister Noda declared to dissolve the lower house. On the day after the Noda's declaration, Abe who was a leader of the LDP (the Liberal Democratic Party) announced his new policy to overcome deflation and to adopt unlimited monetary expansion. Since the LDP was expected to win the election, we can regard it as the first news on Abenomics. D43 is a dummy for the election day of the lower house, while $D 44$ is a dummy for the election day of the upper house. Since each election was held on Sunday, each of them takes one only on the day after the election and zero otherwise. After the two elections, the LDP dominated both the upper and lower houses.

\section{The Estimation Results of Nikkei 225 Futures}

(1) Control Variables

By using Nikkei 225 Futures, we estimated equations (5) and (6) from January 5, 2011 to October 31, 2014. Table 7 reports the estimation results. Although some of the coefficients took the same sign in the two time zones, most coefficients showed different sign and significance level between the two time zones, implying asymmetric responses in daytime and nighttime 
stock price changes.

In the table, none of the constant term was significant. It was true even for the structural break dummy. This implies that even though Nikkei 225 Futures increased dramatically under Abenomics, there was no significant structural break in its average growth when we control the effects of the lag dependent variables and external variables. In contrast, several coefficient dummies indicate that there was a structural change in the effects of the lag dependent variables and external shocks especially in nighttime.

Regarding the effects of the lag dependent variables (DDAY(-1) and DNIGHT(-1)), they were significant before the structural break especially in daytime. This implies that there was some persistency in the intra-daily change of Nikkei 225 Futures before the structural break. However, their coefficient dummies suggest that the persistency became smaller after the structural break. Abenomics might have increased short-term volatility of Nikkei Futures.

Regarding the effects of the external shocks, Hang Seng index in Hong Kong (DHK) had largest impact in daytime, and so did NY Dow $(D D O W)$ in nighttime. In nighttime, FT100 in London (DFT) and US government bond yield (DUSGB) also had significantly positive impact. The results suggest that the impact is larger when the time zone is synchronized. However, the coefficient dummy indicates that several coefficients had a substantial structural change in nighttime. That is, nighttime Nikkei 225 Futures responded to NY Dow, FT100 in London, and US government bond yield more sensitively after Abenomics than before Abenomics. In contrast, a structural change in the effects of the external shocks was, if any, small in daytime. This implies that nighttime investors, who are likely to be foreign investors, became more sensitive to the external shocks since Abenomics started.

\section{(2) News on monetary policy}

Regarding the news shocks on monetary policy, Abe's announcement to adopt unlimited monetary expansion on November 15, 2012 had significantly positive effect on Nikkei 225 Futures both in daytime and in nighttime. But the other announcements under the Shirakawa regime (that is, D102, D103, and D104) never had significantly positive effect. In fact, BOJ's announcement on "The "Price Stability Target" on January 22, 2013 had significantly negative effect both in daytime and in nighttime, while BOJ's announcement on "Enhancement of Monetary Easing" on December 20, 2012 had significantly negative effect in daytime. Overall, the effect of BOJ's announcements under the Shirakawa regime tended to be negative in daytime than in nighttime. 
In contrast, the first statement by Governor Kuroda (D105), which announced the QQE, had large positive effect on Nikkei 225 Futures both in daytime and in nighttime. Noting that the news was revealed in the early afternoon in Japan, this implies that nighttime investors made further reaction to the news after daytime investors had reacted. More interestingly, the coefficient of D105(-1) indicates that the reaction of Nikkei 225 Futures continued on the day after the announcement only in nighttime. The effect of the QQE was controversial soon after the announcement. It was nighttime investors who welcomed the new policy more persistently.

After announcing the QQE on April 4, 2013, the BOJ had made no significant policy change until the extension of QQE on October 31, 2014. Consequently, the reactions of Nikkei 225 Futures were insignificant to most of the BOJ's statements from May 2013 to September 2014. However, the effect of BOJ's announcements tended to be negative in nighttime than in daytime during the QQE period. Specifically, D106, D107, D111, and D112 were significantly negative in nighttime, while D108 was significantly negative but D109 and D110 were significantly positive in daytime. After May, 2013, there were ex-ante market expectations that the BOJ would adopt additional expansionary policy. But each statement denied the additional monetary expansion. The negative coefficients may reflect disappointments of nighttime investors for the statements.

However, the extension of QQE on October 31, 2014 had another large positive effect on Nikkei 225 Futures both in daytime and in nighttime. The extension was a surprise for the market participants. Like the announcement of the QQE in April 8, 2013, nighttime investors made further reaction to the news after daytime investors had reacted

\section{(3) The other news shocks}

Regarding the other news shocks, two dummies for the third arrow (that is, growth strategies) were never significantly positive. But the estimated coefficient of the other news shocks showed remarkably different sign and significance level between the two time zones. In particular, many of the news shocks tend to be positive and more statistically significant only in nighttime at the early stage of Abenomics.

Regarding the news shocks on fiscal policy, D21 and D22 were significantly positive in nighttime, while $D 22$ was significantly negative in daytime. The news shocks on fiscal policy which were revealed at the beginning of Abenomics had positive effect on Nikkei 225 Futures only in nighttime. This implies that only nighttime investors showed positive responses to the fiscal expansion news which were revealed in daytime. However, D25 was significantly 
negative only in nighttime. The fiscal policy news which was announced a year after Abenomics started had negative effect on Nikkei 225 Futures in nighttime.

As for the election news shocks, we can observe significant rises in Nikkei 225 Futures only in nighttime on the day when the late Prime Minister Noda decided to dissolve the lower house (D41) and on the day when the lower house was dissolved (D42). Given the fact that the LDP led by Abe was expected to win the following election, this implies that only nighttime investors showed a significantly positive reaction to the news that Abe's party would dominate the lower house. However, because of no surprise in the election results, neither daytime nor nighttime investors showed a significantly positive response in Nikkei 225 Futures on the election day of the lower house (D43) and the upper house (D44).

VII. The Estimation Results of the Yen-Dollar Rates

(1) Control Variables

By using the intra-daily yen-dollar rate, we estimated equations (7) and (8) from January 5, 2011 to October 31, 2014. Table 8 reports the estimation results. The intra-daily yen-dollar rate has several features which Nikkei 225 Futures does not have. But even for the yen-dollar rate, we still observe asymmetric responses in daytime and nighttime changes.

In the table, the constant term was significantly positive in nighttime, while it was insignificant in daytime. Reflecting carry trade in the foreign exchange market, the yen-dollar rate tended to depreciate in nighttime even before Abenomics. However, the structural break dummy was not significant in either daytime or nighttime. This implies that even though the yen-dollar rate depreciated dramatically under Abenomics, there was no significant structural break in its average growth when we control the effects of the lag dependent variables and external variables. In addition, unlike in Nikkei 225 Futures, there was no structural change in the effect of the lag dependent variables either. However, several coefficient dummies indicate that there was a structural change in the effects of the external shocks.

As in Nikkei 225 Futures, reflecting time synchronization, Hang Seng index in Hong Kong $(D H K)$ had largest positive impact in daytime. But unlike in Nikkei 225 Futures, US government bond yield (DUSGB) had significantly negative impact in daytime. In nighttime, NY Dow $(D D O W)$ and FT100 in London (DFT) had significantly positive impact, while US government bond yield had significantly negative impact. The results may suggest that the impact is larger when the time zone is synchronized. However, the synchronized change of the 
euro-dollar rate had large positive impact on the yen-dollar rate only in nighttime.

The coefficient dummies indicate that the effects of NY DOW, Hang Seng index, and US government bond yield had a substantial structural change both in daytime and in nighttime. Unlike in Nikkei 225 Futures, the intra-daily yen-dollar rate responded to external shocks more sensitively after Abenomics than before Abenomics not only in nighttime but also in daytime. However, the coefficient dummies took opposite sign for DDOW and DHK. Moreover, the coefficient dummy of the euro-dollar rate $(D E U R O)$ was significant only in nighttime. This implies that the effects of the external shocks were not symmetric between daytime and nighttime investors.

\section{(4) News on monetary policy}

Regarding the news shocks on monetary policy, Abe's announcement on November 15, 2012 had significantly positive effect on the yen-dollar rate only in daytime. BOJ's announcement on "The "Price Stability Target" on January 22, 2013 had significantly negative effect both in daytime and in nighttime. However, unlike in Nikkei 225 Futures, D102 and D104 under the Shirakawa regime had significantly positive effect on the yen-dollar rate in nighttime. Under the Shirakawa regime, nighttime investors reacted to the BOJ's announcements more in nighttime than in daytime, even though each announcement was made in daytime.

As in Nikkei 225 Futures, the first statement by Governor Kuroda (D105), which announced the QQE, had large positive effect on the yen-dollar rate both in daytime and in nighttime. After the QQE was announced in the early afternoon in Japan, daytime investors first made large reaction and then nighttime investors made additional reaction in the foreign exchange market. But as in Nikkei 225 Futures, the coefficient of D105(-1) indicates that the reaction of the yen-dollar rate continued on the next day only in nighttime. Even in the yen-dollar rate, it was nighttime investors who made more persistent responses to the new policy shock.

Because of no significant additional policy change, the reactions of the yen-dollar rate were insignificant to most of the BOJ's statements from May 2013 to September 2014. However, unlike in Nikkei 225 Futures, the effect of BOJ's announcements tended to have a negative effect on the yen-dollar rate in daytime than in nighttime from May 2013 to August 2013. Specifically, D106, D107, and D108 were significantly negative in daytime, while D107 was significantly negative in daytime during the period.

In contrast, the extension of QQE on October 31, 2014 had large positive effect on the 
yen-dollar rate only in daytime. The feature is also in marked contrast with Nikkei 225 Futures which showed a large positive response both in daytime and in nighttime

(5) The other news shocks

Regarding the other news shocks, the election news shocks had less significant effect on the yen-dollar rate than on Nikkei 225 Futures. However, the news shocks on fiscal policy which were revealed at the beginning of Abenomics still had positive effect on the yen-dollar rate mostly in nighttime. Specifically, D21 and D23 were significantly positive in nighttime, while D23 was significantly positive but D24 was significantly negative in daytime. This implies that nighttime investors were likely to show a positive response to the fiscal expansion news at the beginning of Abenomics. However, D25 was significantly negative only in nighttime. As in Nikkei 225 Futures, the fiscal policy news which was announced a year after Abenomics started had negative effect on the yen-dollar rate in nighttime.

As in Nikkei 225 Futures, two dummies for the third arrow (that is, growth strategies) were never significantly positive in nighttime. But D31 was significantly negative in daytime. As in Nikkei 225 Futures, neither daytime nor nighttime investors welcomed the third arrow (that is, growth strategies) in the foreign exchange market.

\section{Concluding Remarks}

The Japanese economy had experienced prolonged deflation since the late 1990s. In order to 'reflate' its economy, Abenomics implemented quantitative easing, fiscal policy through expanding government spending, and provide economic growth strategies. Both the stock market and the foreign exchange market reacted to the new policy regime very favorably at least before the market crash on May 23, 2013. But there was conspicuous asymmetric behavior between local and foreign investors under the new regime. In this paper, we explored who reacted to Abenomics favorably and when it happened.

We found that foreign investors' responses to the new regime played a leading role in improving the market sentiments. In particular, we found that before May 2013, most of the news shocks on Abenomics had a significant effect only on nighttime changes even if they were revealed in daytime. Noting that foreign investors tend to trade in Japan nighttime, it suggests that the dramatic market responses under Abenomics happened only in time zones when foreign investors were active. 
It is beyond scope of this paper to see why there were asymmetric responses between local and foreign investors. We may attribute them to asymmetric risk tolerance or asymmetric information across investors. Overconfidence by foreign investors and pessimistic views by local investors may explain the asymmetry. Although we need further data and evidence, it will be an important research agenda to see why only foreign investors reacted to Abenomics favorably. However, the asymmetry might have been less significant after the market crash on May 23, 2013. 


\section{References}

Andrews, D.W K, (1993), "Tests for Parameter Instability and Structural Change with Unknown Change Point," Econometrica, vol. 61(4), pp.821-56.

Bai, J., and P. Perron, (2003), "Computation and Analysis of Multiple Structural Change Models", Journal of Applied Econometrics, vol. 18, pp.1-22.

Bernanke, B.S., V. R. Reinhart, and B. P. Sack, (2004), "Monetary Policy Alternatives at the Zero Bound: An Empirical Assessment,” Brookings Papers on Economic Activity, no. 2 (Fall 2004), pp. 1-78.

Fujiwara, I., (2006), "Evaluating Monetary Policy when Nominal Interest Rates Are Almost Zero," Journal of the Japanese and International Economies 20(3), pp.434-453.

Fukuda, S., (2012) Market-specific and Currency-specific Risk during the Global Financial Crisis: Evidence from the Interbank Markets in Tokyo and London, Journal of Banking and Finance, 36(12), 3185-3196.

Honda, Y., Y. Kuroki, and M. Tachibana, (2007), “An Injection of Base Money at Zero Interest Rates: Empirical Evidence from the Japanese Experience 2001-2006," Osaka University, Discussion Papers in Economics and Business, No.07-08.

Honda, Y., (2014), "The Effectiveness of Nontraditional Monetary Policy: The Case of Japan," Japanese Economic Review 65(1), pp. 1-23.

Kohn, D., and B. Sack, (2003), "Central Bank Talk: Does It Matter and Why?" Board of Governors of the Federal Reserve System, Finance and Economics Discussion Series, 2003-55.

Krugman, P., (2013), “Japan Steps Out,” New York Times, January 13, 2013.

IMF, (2013), “Japan: 2013 Article IV Consultation,” IMF Country Report No. 13/253, August 5, 2013.

Ito, T., and V.V. Roley, (1987) "News from the U.S. and Japan: Which moves the yen/dollar exchange rate?" Journal of Monetary Economics, Volume 19, Issue 2, Pages 255-277.

Gambacorta, L., B. Hofmann, and G. Peersman, (2014), "The Effectiveness of Unconventional Monetary Policy at the Zero Lower Bound: A Cross-Country Analysis," Journal of Money, Credit, and Banking 46(4), pp. 615-642.

Koeda, J., (2013), "Endogenous Monetary Policy Shifts and the Term Structure: Evidence from Japanese Government Bond Yields," Journal of the Japanese and International Economies 29, pp.170-188.

Krishnamurthy, A., and A. Vissing-Jorgensen, (2011), "The Effects of Quantitative Easing on 
Interest Rates: Channels and Implications for Policy," Brooking Papers on Economic Activity, Fall 2011, pp.215-265.

Lambert, F. and K. Ueda, (2014), "The Effects of Unconventional Monetary Policies on Bank Soundness," IMF Working Paper WP/14/152.

Nakazono, Y., and K. Ueda, (2013), "Policy Commitment and Market Expectations: Lessons Learned from Survey Based Evidence under Japan's Quantitative Easing Policy,” Japan and the World Economy 25-26, pp. 102-13

Oda, N., and T. Nagahata, (2008), "On the Function of the Zero Interest Rate Commitment: Monetary Policy Rules in the Presence of the Zero Lower Bound on Interest Rates," Journal of the Japanese and International Economies 22(1), pp.34-67.

Rogers, J. H., Scotti, C., and Wright J. H., (2014), "Evaluating Asset-Market Effects of Unconventional Monetary Policy: A Multi-country Review," Economic Policy 80, pp. 749-88.

Rosa, C., (2012), "How "Unconventional" are Large-Scale Asset Purchases? The Impact of Monetary Policy on Asset Prices," FRB of New York Staff Report No. 560.

Tsutsui, Y., and K. Hirayama, (2010), "How Fast Do Tokyo and New York Stock Exchanges Respond to Each Other? An Analysis with High-Frequency Data,” Japanese Economic Review, 61(2), pp. 175-201.

Ueda, K., (2012), "Deleveraging and Monetary Policy: Japan since the 1990s and the United States since 2007," Journal of Economic Perspectives, vol. 26(3), pp. 177-202.

Ueda, K., (2013), "Response of Asset Prices to Monetary Policy under Abenomics," Asian Economic Policy Review, vol. 8(2), pp. 252-269. 
Table 1. Correlation between Net Purchases and Asset Price Changes

(1) Foreign investors

\begin{tabular}{|l|r|r|}
\hline & stock price & exchange rate \\
\hline Jan. 12 - Oct. 14 & 0.652 & 0.530 \\
Jan. 2012 - Oct. 2012 & 0.623 & 0.399 \\
Nov. 2012 - Dec. 2013 & 0.691 & 0.557 \\
Dec. 2012 - May 2013 & 0.779 & 0.683 \\
Jan. 2014 - Oct. 2014 & 0.694 & 0.613 \\
\hline
\end{tabular}

(2) Local institutions

\begin{tabular}{|l|r|r|}
\hline & stock price & exchange rate \\
\hline Jan. 12 - Oct. 14 & -0.206 & -0.232 \\
Jan. 2012 - Oct. 2012 & -0.171 & -0.229 \\
Nov. 2012 - Dec. 2013 & -0.229 & -0.185 \\
Dec. 2012 - May 2013 & -0.335 & -0.234 \\
Jan. 2014 - Oct. 2014 & 0.204 & -0.058 \\
\hline
\end{tabular}

(3) Local individuals

\begin{tabular}{|l|r|r|}
\hline & stock price & exchange rate \\
\hline Jan. 12 - Oct. 14 & -0.718 & -0.491 \\
Jan. 2012 - Oct. 2012 & -0.788 & -0.297 \\
Nov. 2012 - Dec. 2013 & -0.690 & -0.477 \\
Dec. 2012 - May 2013 & -0.811 & -0.638 \\
Jan. 2014 - Oct. 2014 & -0.847 & -0.753 \\
\hline
\end{tabular}


Table 2. Basic Statistics of Intra-daily Changes of Nikkei 225

(1) Nikkei 225 Futures

\begin{tabular}{|l|r|r|r|r|}
\hline & \multicolumn{2}{|l|}{ laverage } & \multicolumn{2}{l|}{ standard de viation } \\
\cline { 2 - 5 } & 9am-3:15pm & $3: 15 \mathrm{pm}-6: 15 \mathrm{am}$ & 9am-3:15pm & $3: 15 \mathrm{pm}-6: 15 \mathrm{am}$ \\
\hline full sample & -2.957 & 8.606 & 130.472 & 107.799 \\
before Nov. 30, 2012 & -3.080 & 0.897 & 86.846 & 82.368 \\
\hline after Dec. 3, 2012 & -2.672 & 26.520 & 197.984 & 149.950 \\
\hline after April 4, 2013 & -4.758 & 13.669 & 234.705 & 166.156 \\
\hline
\end{tabular}

(2) Nikkei 225

\begin{tabular}{|l|r|r|r|r|}
\hline & \multicolumn{2}{l|}{ laverage } & \multicolumn{2}{l|}{ standard deviation } \\
\cline { 2 - 5 } & $9: 15 \mathrm{am}-3 \mathrm{pm}$ & 3pm-9:15am & $9: 15 \mathrm{am}-3 \mathrm{pm}$ & 3pm-9:15am \\
\hline full sample & -2.778 & 9.031 & 109.603 & 117.909 \\
before Nov. 30, 2012 & -2.999 & 1.348 & 66.000 & 94.027 \\
after Dec. 3, 2012 & -2.259 & 27.060 & 173.466 & 159.426 \\
after April 4, 2013 & -0.745 & 17.906 & 210.993 & 182.883 \\
\hline
\end{tabular}

Table 3. Basic Statistics of Intra-daily Changes of Yen-dollar Exchange Rates

\begin{tabular}{|l|r|r|r|r|r|r|}
\hline & \multicolumn{1}{l|}{ average } & \multicolumn{3}{l|}{ standard deviation } \\
\cline { 2 - 7 } & \multicolumn{1}{|l|}{ 9am-5pm } & \multicolumn{1}{l|}{ 5pm-9am } & 5pm-7am & 9am-5pm & 5pm-9am & 5pm-7am \\
\hline full sample & -0.015 & 0.039 & 0.001 & 0.357 & 0.466 & 0.401 \\
before Nov. 30, 2012 & -0.019 & 0.021 & -0.005 & 0.304 & 0.334 & 0.307 \\
after Dec. 3, 2012 & -0.006 & 0.081 & 0.016 & 0.459 & 0.679 & 0.564 \\
after April 4, 2013 & 0.034 & 0.002 & -0.041 & 0.534 & 0.708 & 0.582 \\
\hline
\end{tabular}


Table 4. The Quandt-Andrews Test

(1) Daytime Change of the Stock Price Index

\begin{tabular}{|l|l|l|l|r|}
\cline { 2 - 5 } \multicolumn{1}{l|}{} & Nikkei 225 Futures & \multicolumn{3}{l|}{ Nikkei 225 (spot) } \\
\hline Statistic & Break day & Value & Break day & \multicolumn{1}{l|}{ Value } \\
\hline Maximum LR F-statistic & Jan. 24, 2013 & $5.10 * * *$ & April. 1, 2014 & 2.59 \\
\hline Maximum Wald F-statistic & Jan. 24, 2013 & $35.70 * * *$ & April. 1, 2014 & 18.10 \\
\hline
\end{tabular}

(2) Nighttime Change of the Stock Price Index

\begin{tabular}{|l|l|l|l|l|}
\cline { 2 - 5 } \multicolumn{1}{l|}{} & \multicolumn{2}{|l|}{ Nikkei 225 Futures } & \multicolumn{2}{l|}{ Nikkei 225 (spot) } \\
\hline Statistic & Break day & Value & Break day & \multicolumn{1}{l|}{ Value } \\
\hline Maximum LR F-statistic & Dec. 31, 2012 & $20.04 * * *$ & Jan. 3, 2013 & $8.82 * * *$ \\
\hline Maximum Wald F-statistic & Dec. 31, 2012 & $140.25 * * *$ & Jan. 3, 2013 & $61.72 * * *$ \\
\hline
\end{tabular}

(3) Daytime Change of the Yen-Dollar Rate

\begin{tabular}{|l|l|r|}
\hline Statistic & Break day & \multicolumn{1}{|c|}{ Value } \\
\hline Maximum LR F-statistic & Feb. 1, 2013 & $4.77 * * *$ \\
\hline Maximum Wald F-statistic & Feb. 1, 2013 & $38.18 * * *$ \\
\hline
\end{tabular}

(4) Nighttime Change of the Yen-Dollar Rate

\begin{tabular}{|l|l|l|l|l|}
\cline { 2 - 5 } \multicolumn{1}{l|}{} & Nighttime I & & \multicolumn{3}{l|}{ Nighttime II } \\
\hline Statistic & Break day & Value & Break day & \multicolumn{1}{l|}{ Value } \\
\hline Maximum LR F-statistic & Dec. 28, 2012 & $15.43 * * *$ & Dec. 28, 2012 & $14.92 * * *$ \\
\hline Maximum Wald F-statistic & Dec. 28, 2012 & $123.40 * * *$ & Dec. 28, 2012 & $119.39 * * *$ \\
\hline
\end{tabular}

Notes 1$) *$ Significant at the $10 \%$ level, and $* * *$ Significant at the $1 \%$ level.

2) Null hypothesis: No breakpoints within $15 \%$ trimmed data.

3) Daytime of the Nikkei 225 Futures $=6: 15 \mathrm{am}$ to $3: 15 \mathrm{pm}$ in Tokyo,

Daytime of the Nikkei 225 (spot) $=9: 15 \mathrm{am}$ to $3 \mathrm{pm}$ in Tokyo,

Nighttime of the Nikkei 225 Futures $=3: 15 \mathrm{pm}$ to $6: 15 \mathrm{am}$ in the following business day,

Nighttime of the Nikkei 225 (spot) = 9am to 9:15am in the following business day.

4) Daytime of the yen-dollar rate $=9 \mathrm{am}$ to $5 \mathrm{pm}$ in Tokyo,

Nighttime I of the yen-dollar rate $=5 \mathrm{pm}$ to $9 \mathrm{am}$ in Tokyo in the following business day,

Nighttime II of the yen-dollar rate $=5 \mathrm{pm}$ in Tokyo to $5 \mathrm{pm}$ in New York. 
Table 5. The Bai-Perron Test

(1) Daytime Change of the Stock Price Index

\begin{tabular}{|c|c|c|c|c|}
\hline & \multicolumn{2}{|c|}{ Nikkei 225 Futures } & \multicolumn{2}{|c|}{ Nikkei 225 (spot) } \\
\hline Break Test & Break date & $\mathrm{F}$-statistic & Break date & F-statistic \\
\hline 0 vs. 1 & Jan. 24, 2013 & $35.70 * * *$ & none & 18.11 \\
\hline 1 vs. 2 & & 19.16 & & \\
\hline
\end{tabular}

(2) Nighttime Change of the Stock Price Index

\begin{tabular}{|l|l|l|l|l|}
\cline { 2 - 5 } \multicolumn{1}{c|}{} & \multicolumn{2}{|l|}{ Nikkei 225 Futures } & \multicolumn{2}{l|}{ Nikkei 225 (spot) } \\
\hline Break Test & Break date & F-statistic & Break date & F-statistic \\
\hline 0 vs. 1 & Dec. 31,2012 & $140.25 * * *$ & Jan. 3, 2013 & $61.72 * * *$ \\
1 vs. 2 & Aug. 10, 2011 & $25.37 * *$ & Jul. 31, 2013 & $26.04 * *$ \\
2 vs. 3 & Feb. 14, 2014 & $24.85 *$ & & 21.81 \\
3 vs. 4 & & 13.49 & & \\
\hline
\end{tabular}

(3) Daytime Change of the Yen-Dollar Rate

\begin{tabular}{|l|l|l|}
\hline Break Test & Break date & F-statistic \\
\hline 0 vs. 1 & Feb. 1,2013 & $38.18 * * *$ \\
\hline 1 vs. 2 & Jun. 5,2012 & $36.65 * * *$ \\
\hline 2 vs. 3 & & 21.69 \\
\hline
\end{tabular}

(4) Nighttime Change of the Yen-Dollar Rate

\begin{tabular}{|c|c|c|c|c|c|c|}
\hline & Nighttime I & & & Nighttime II & & \\
\hline Break Test & Break date & F-statistic & & Break date & F-statistic & \\
\hline 0 vs. 1 & Dec. 28,2012 & 123.40 & $* * *$ & Dec. 28, 2012 & 119.39 & $* * *$ \\
\hline 1 vs. 2 & Aug. 28, 2013 & 34.82 & $* * *$ & Aug. 5, 2012 & 33.84 & $* * *$ \\
\hline 2 vs. 3 & & 21.38 & & Feb. 14, 2014 & 27.96 & ** \\
\hline 3 vs. 4 & & & & & 12.56 & \\
\hline
\end{tabular}

Notes 1) Break test options: Trimming 0.15, Max. breaks 5 .

2) F-statistic means "Scaled F-statistic".

3) * Significant at the $10 \%$ level, ** Significant at the 5\% level, and *** Significant at the $1 \%$ level. 
Table 6. The list of each type of news shocks

(1) News shocks on BOJ's monetary policy (the first arrow)

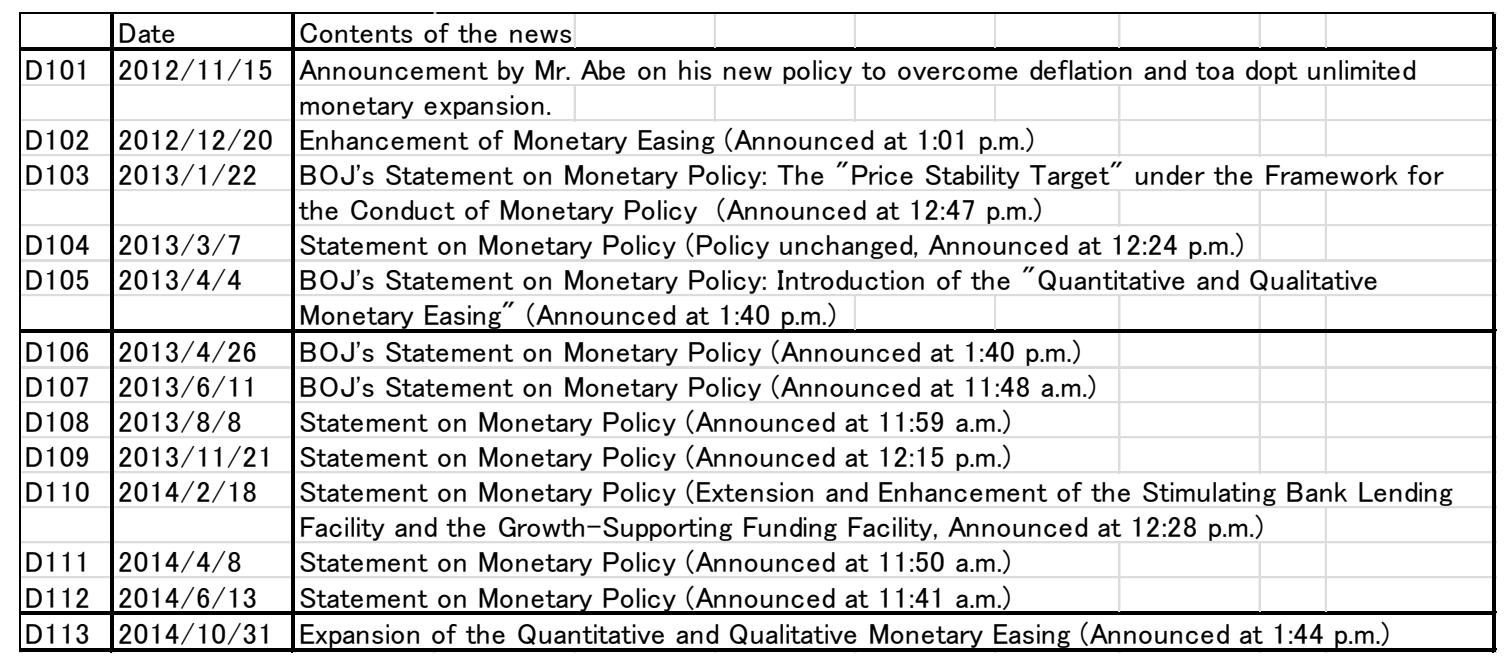

\section{(2) News shocks on Japan's fiscal policy (the second arrow)}



\section{(3) News shocks on Japan's growth strategies (the third arrow)}

\begin{tabular}{|l|l|l|}
\hline & Date & Contents of the news \\
\hline D31 & $2013 / 6 / 14$ & $\begin{array}{l}\text { Announcement of Japan Revitalization Strategy - JAPAN is BACK -". } \\
\text { Announcement of "Basic Policies for Economic and Fiscal Management and Reform }\end{array}$ \\
D32 & $2014 / 6 / 24$ & $\begin{array}{l}\text { Announcement of the revised "Japan Revitalization Strategy" } \\
\text { Announcement of "Basic Policies for Economic and Fiscal Management and Reform 2014" }\end{array}$ \\
\hline
\end{tabular}

\section{(4) News shocks on elections}

\begin{tabular}{|l|l|l|}
\hline & Date & Contents of the news \\
\hline D41 & $2012 / 11 / 14$ & Declaration by the Late Prime Minister Noda to dissolve the lower house. \\
\hline D42 & $2012 / 11 / 16$ & Dissolution of the lower house of parliament \\
\hline D43 & $2012 / 12 / 17$ & The day after the election day of the lower house. \\
\hline D44 & $2013 / 7 / 22$ & The day after the election day of the upper house. \\
\hline
\end{tabular}


Table 7. The Estimation Results of Nikkei 225 Futures

\begin{tabular}{|c|c|c|c|c|c|c|c|}
\hline & \multirow[b]{2}{*}{ Variable } & \multicolumn{2}{|c|}{ Daytime Change } & & \multicolumn{2}{|c|}{ Nighttime Change } & \\
\hline & & Coef. & t-Stat. & & Coef. & t-Stat. & \\
\hline & Constant & -0.029 & -0.67 & & -0.001 & -0.03 & \\
\hline & Dum & 0.051 & 0.80 & & 0.049 & 1.35 & \\
\hline & DDAY(-1) & 18.368 & 3.56 & $* * *$ & -27.395 & -9.35 & $* * *$ \\
\hline & Dum*DDAY(-1) & -26.512 & -3.89 & $* * *$ & 1.699 & 0.45 & \\
\hline control & DNIGHT(-1) & -17.239 & -2.02 & $* *$ & 3.564 & 1.03 & \\
\hline \multirow[t]{10}{*}{ variables } & Dum*DNIGHT(-1) & 6.766 & 0.61 & & -1.922 & -0.44 & \\
\hline & DDOW & -29.277 & -3.60 & $* * *$ & 57.126 & 15.46 & $* * *$ \\
\hline & Dum*DDOW & 13.895 & 1.01 & & 40.180 & 6.57 & $* * *$ \\
\hline & DFT & 4.717 & 0.85 & & 9.139 & 2.65 & $* * *$ \\
\hline & Dum*DFT & 5.345 & 0.55 & & 10.369 & 1.73 & * \\
\hline & DHK & 35.536 & 9.06 & $* * *$ & -0.061 & -0.02 & \\
\hline & Dum*DHK & 2.485 & 0.36 & & -1.854 & -0.44 & \\
\hline & DUSGB & -0.376 & -0.32 & & 3.625 & 5.44 & $* * *$ \\
\hline & Dum*DUSGB & -3.793 & -1.92 & * & 3.228 & 3.01 & $* * *$ \\
\hline & D101 & 1.845 & 1.89 & $*$ & 1.274 & 2.27 & $* *$ \\
\hline 1st arrow & D102 & -1.693 & -1.73 & * & 0.850 & 1.52 & \\
\hline (monetary & D103 & -1.703 & -1.72 & $*$ & -1.618 & -2.87 & $* * *$ \\
\hline \multirow[t]{11}{*}{ policy) } & D104 & -0.552 & -0.57 & & 0.377 & 0.67 & \\
\hline & D105 & 3.964 & 4.04 & $* * *$ & 3.524 & 6.17 & $* * *$ \\
\hline & D105(+1) & 0.036 & 0.03 & & 2.180 & 3.82 & $* *$ \\
\hline & D106 & -0.341 & -0.35 & & -0.958 & -1.72 & * \\
\hline & D107 & -0.579 & -0.59 & & -2.449 & -4.38 & $* * *$ \\
\hline & D108 & -1.508 & -2.18 & ** & -0.047 & -0.12 & \\
\hline & D109 & 1.878 & 1.93 & * & 0.499 & 0.89 & \\
\hline & D110 & 2.519 & 2.58 & $* * *$ & 0.369 & 0.65 & \\
\hline & D111 & -1.472 & -1.50 & & -1.788 & -3.19 & $* * *$ \\
\hline & D112 & 1.445 & 1.48 & & -1.836 & -3.27 & $* * *$ \\
\hline & D113 & 4.110 & 4.20 & $* * *$ & 2.760 & 4.87 & $* * *$ \\
\hline
\end{tabular}


Table 7. The Estimation Results of Nikkei 225 Futures (continued)

\begin{tabular}{|c|c|c|c|c|c|c|}
\hline & \multirow[b]{2}{*}{ Variable } & \multicolumn{2}{|c|}{ Daytime Change } & \multicolumn{2}{|c|}{ Nighttime Change } & \\
\hline & & Coef. & t-Stat. & Coef. & t-Stat. & \\
\hline & D21 & 0.311 & 0.55 & 0.749 & 2.32 & $* *$ \\
\hline \multirow[t]{4}{*}{ 2nd arrow } & D22 & -1.053 & $-1.77 *$ & 0.721 & 2.16 & $* *$ \\
\hline & D23 & 0.816 & 1.37 & 0.457 & 1.34 & \\
\hline & D24 & -0.138 & -0.23 & 0.035 & 0.10 & \\
\hline & $\mathrm{D} 25$ & -0.589 & -1.04 & -0.557 & -1.72 & $*$ \\
\hline \multirow[t]{3}{*}{ 3rd arrow } & D31 & -1.063 & $-1.88 *$ & -0.159 & -0.49 & \\
\hline & D32 & 0.202 & 0.36 & 0.076 & 0.24 & \\
\hline & D41 & -0.328 & -0.34 & 1.050 & 1.88 & $*$ \\
\hline \multirow[t]{3}{*}{ election } & D42 & 1.227 & 1.25 & 1.303 & 2.32 & $* *$ \\
\hline & D43 & 0.732 & 0.75 & -0.087 & -0.15 & \\
\hline & D44 & -1.115 & -1.14 & -0.328 & -0.59 & \\
\hline \multicolumn{2}{|c|}{ Adjusted R-squared } & & 0.198 & & 0.676 & \\
\hline
\end{tabular}

Notes 1) Each dependent variable is multiplied by 100.

2) * Significant at the $10 \%$ level, ** Significant at the 5\% level, and *** Significant at the $1 \%$ level.

3) $\mathrm{DDAY}=$ Daytime change of Nikkei 225 Futures, DNIGHT $=$ Nighttime change of Nikkei 225 Futures, DDOW = Daily change of NY Dow, DFT = Daily change of FT100 in London, DHK = Daily change of Hang Seng index in Hong Kong, DUSGB = Daily change of US government bond yield, and Dum = Structural change dummy.

4) Definitions of the other dummy variables are available in Table 6. 
Table 8. The Estimation Results of Yen-Dollar Rates

\begin{tabular}{|c|c|c|c|c|c|c|}
\hline & \multirow[b]{2}{*}{ Variable } & \multicolumn{2}{|c|}{ Daytime Change } & \multicolumn{3}{|c|}{ Nighttime Change } \\
\hline & & Coef. & t-Stat. & Coef. & t-Stat. & \\
\hline & Constant & -0.024 & -1.65 & 0.037 & 2.25 & $* *$ \\
\hline & Dum & 0.025 & 1.13 & -0.008 & -0.34 & \\
\hline & DDAY(-1) & -9.095 & $-2.30 * *$ & 5.456 & 1.23 & \\
\hline & Dum*DDAY(-1) & 7.689 & 1.18 & 0.414 & 0.06 & \\
\hline \multirow[t]{2}{*}{ control } & DNIGHT(-1) & -9.696 & $-2.51 * *$ & 0.468 & 0.11 & \\
\hline & Dum*DNIGHT(-1) & 10.766 & $1.98 * *$ & -5.149 & -0.97 & \\
\hline \multirow[t]{11}{*}{ variables } & DDOW & -0.669 & -0.29 & -1.642 & -0.64 & \\
\hline & Dum*DDOW & -10.274 & $-2.61 * * *$ & 26.294 & 6.36 & $* * *$ \\
\hline & DFT & -0.762 & -0.40 & 3.869 & 1.71 & $*$ \\
\hline & Dum*DFT & -3.838 & -1.15 & 6.902 & 1.75 & $*$ \\
\hline & DHK & 4.163 & $2.90 * * *$ & 0.160 & 0.12 & \\
\hline & Dum*DHK & 5.385 & $2.25 * *$ & -4.976 & -1.98 & $* *$ \\
\hline & DEURODAY & 0.289 & 0.69 & 4.093 & 9.28 & $* * *$ \\
\hline & Dum*DEURODAY & 0.224 & 0.31 & 1.859 & 2.60 & $* * *$ \\
\hline & DUSGB & -13.740 & $-2.47 * *$ & -15.206 & -4.63 & $* * *$ \\
\hline & Dum*DUSGB & -39.948 & $-3.28 * * *$ & -10.870 & -1.97 & $* *$ \\
\hline & D101 & 0.962 & $2.88^{* * *}$ & 0.370 & 1.01 & \\
\hline 1st arrow & D102 & -0.370 & -1.11 & 0.604 & 1.65 & $*$ \\
\hline (monetary & D103 & -0.586 & $-1.75 *$ & -0.818 & -2.22 & $* *$ \\
\hline \multirow[t]{11}{*}{ policy) } & D104 & 0.107 & 0.32 & 0.776 & 2.09 & $* *$ \\
\hline & D105 & 2.611 & $7.72 * * *$ & 1.345 & 3.62 & $* * *$ \\
\hline & D105(+1) & 0.106 & 0.28 & 2.641 & 6.59 & $* * *$ \\
\hline & D106 & -0.669 & $-2.00 * *$ & -0.276 & -0.75 & \\
\hline & D107 & -0.581 & $-1.74 *$ & -1.608 & -4.37 & $* * *$ \\
\hline & D108 & -0.421 & $-1.77 *$ & 0.356 & 1.37 & \\
\hline & D109 & 0.371 & 1.11 & 0.540 & 1.47 & \\
\hline & D110 & 0.511 & 1.53 & -0.036 & -0.10 & \\
\hline & D111 & -0.422 & -1.26 & -0.665 & -1.81 & $*$ \\
\hline & D112 & 0.078 & 0.23 & 0.056 & 0.15 & \\
\hline & D113 & 1.681 & $4.97 * * *$ & 0.365 & 0.99 & \\
\hline
\end{tabular}


Table 8. The Estimation Results of Yen-Dollar Rates (continued)

\begin{tabular}{|c|c|c|c|c|c|}
\hline & \multirow[b]{2}{*}{ Variable } & \multicolumn{2}{|c|}{ Daytime Change } & \multicolumn{2}{|c|}{ Nighttime Change } \\
\hline & & Coef. & t-Stat. & Coef. & t-Stat. \\
\hline & D21 & 0.168 & 0.87 & 0.436 & $2.05^{* *}$ \\
\hline \multirow[t]{4}{*}{ 2nd arrow } & D22 & 0.033 & 0.17 & -0.135 & -0.63 \\
\hline & D23 & 0.401 & $1.96 *$ & 0.699 & $3.07 * * *$ \\
\hline & D24 & -0.413 & $-2.02 * *$ & -0.004 & -0.02 \\
\hline & D25 & 0.032 & 0.17 & -0.383 & $-1.79 *$ \\
\hline \multirow[t]{3}{*}{ 3rd arrow } & D31 & -0.437 & $-2.23 * *$ & -0.069 & -0.32 \\
\hline & D32 & 0.013 & 0.07 & 0.059 & 0.28 \\
\hline & D41 & 0.543 & 1.63 & 0.374 & 1.01 \\
\hline \multirow[t]{3}{*}{ election } & D42 & 0.069 & 0.20 & 0.651 & $1.76 *$ \\
\hline & D43 & -0.068 & -0.20 & -0.414 & -1.12 \\
\hline & D44 & -0.406 & -1.22 & -0.564 & -1.54 \\
\hline \multicolumn{2}{|c|}{ Adjusted R-squared } & & 0.170 & & 0.391 \\
\hline
\end{tabular}

Notes 1) Each dependent variable is multiplied by 100.

2) * Significant at the $10 \%$ level, ** Significant at the 5\% level, and *** Significant at the $1 \%$ level.

3) DDAY = Daytime change of the yen-dollar rate, DNIGHT $=$ Nighttime change of the yen-dollar rate, and DEURO = Daytime change of the euro-dollar rate when DDAY is dependent variable and nighttime change of the euro-dollar rate when DNIGHT is dependent variable,

4) Definitions of the other variables are available in Tables 6 and 7. 
Figure 1. The Japanese stock price index and the Yen-dollar exchange rates

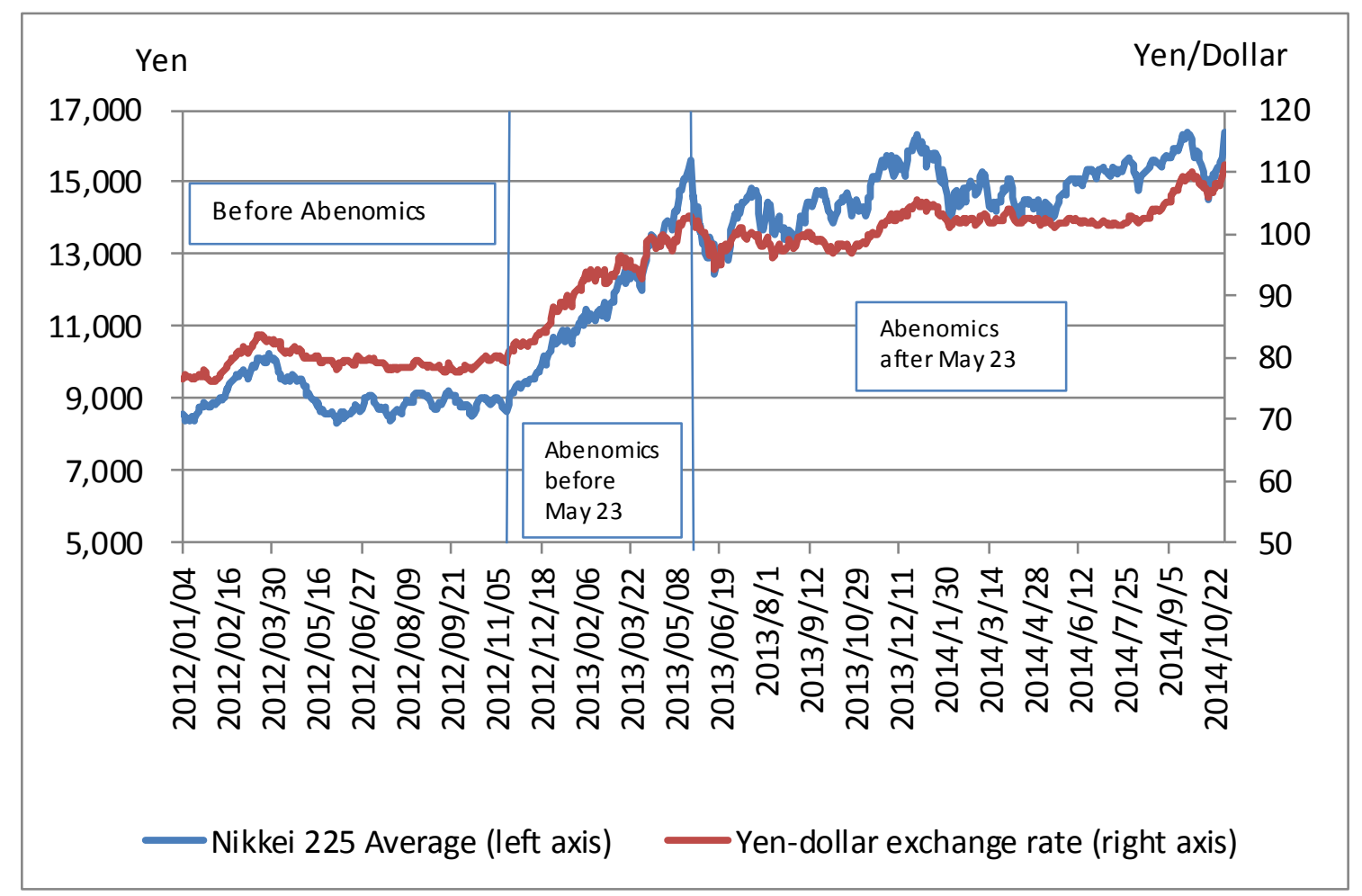

(Source) Nikkei, Financial Quest. 
Figure 2. Trading Value by Investor Type TSE 1st Section



(Source) Tokyo Stock Exchange.

Figure 3. Investments in Listed Stocks by Nonresidential Investors by region

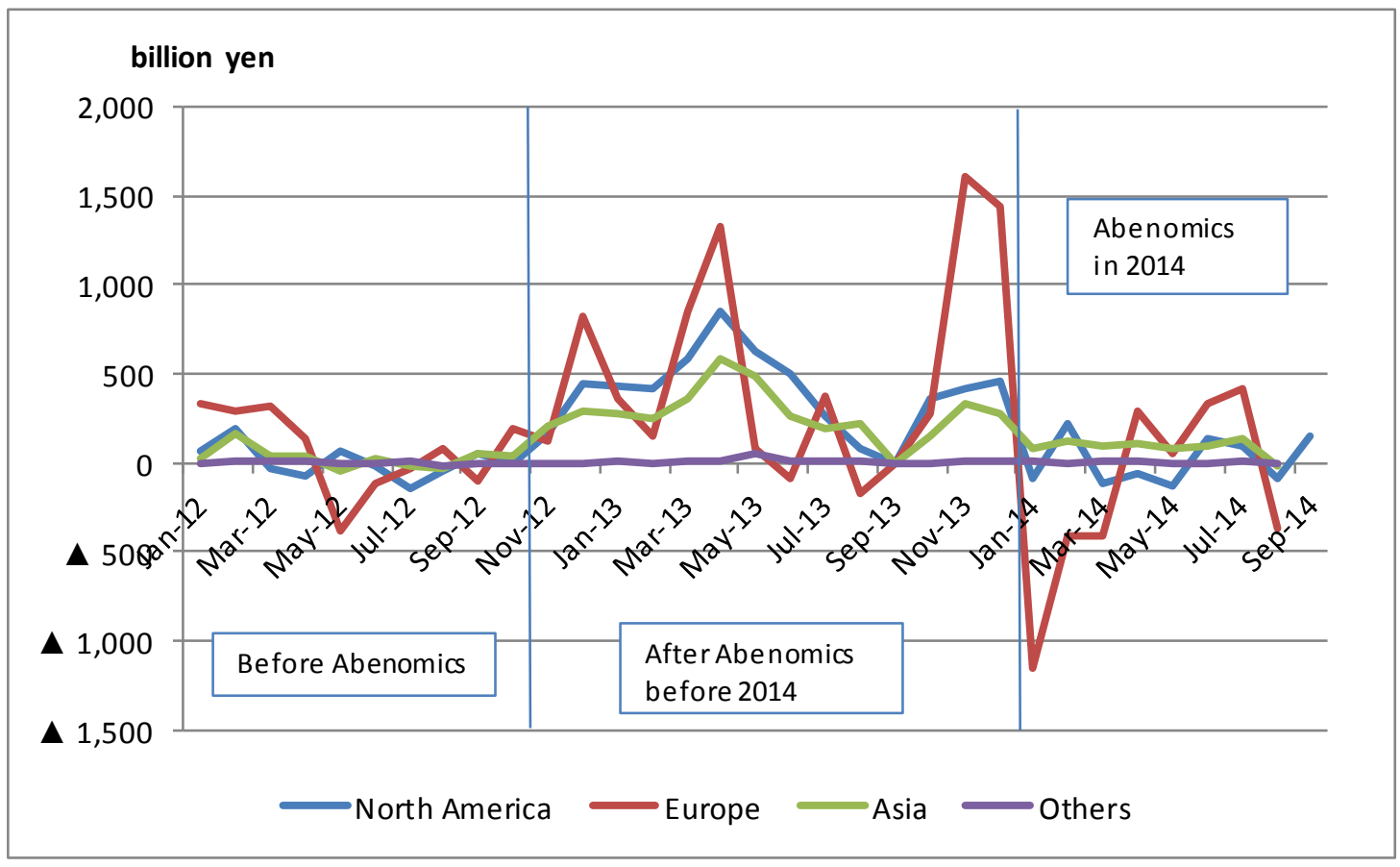

(Source) Tokyo Stock Exchange. 
Figure 4. Japan Daytime and Nighttime

(1) Nikkei 225 Futures

$\begin{array}{cccc}\text { 6:15 am } & 3: 15 \mathrm{pm} & 6: 15 \text { am } \\ \text { Japan daytime } & \text { Japan nighttime } & \text { open } \\ \text { 9am } & & & \end{array}$

(2) Nikkei 225

\begin{tabular}{clll:} 
9:15 am & 3pm & 9am 9:15 am \\
$:$ Japan daytime & Japan nighttime & \\
\hdashline open & closed & open
\end{tabular}

(3) The Yen-Dollar Exchange Rates I

$\begin{array}{ccccc}9 \text { 9am } & & 5 \text { pm } & 9 \text { am } \\ & \text { Japan daytime } & & \text { Japan nighttime } & \text { open }\end{array}$

(4) The Yen-Dollar Exchange Rates II

\begin{tabular}{cccc}
$9 a m$ & $5 p m$ & 7 am \\
\hdashline & Japan daytime & Japan nighttime & open
\end{tabular}


Figure 5. Accumulated Changes of Nikkei 225 (October 31, $2012=0$ )

\section{(1) Nikkei 225 Futures}

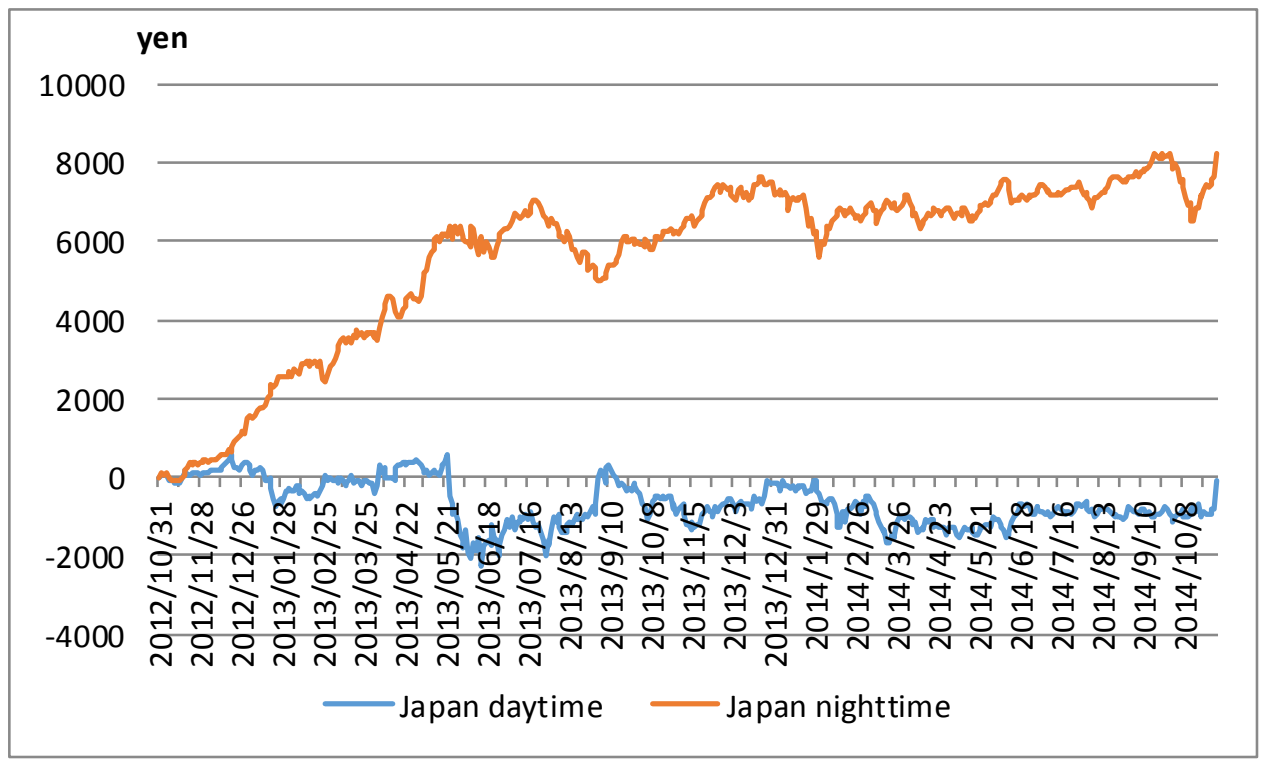

\section{(2) Nikkei 225}

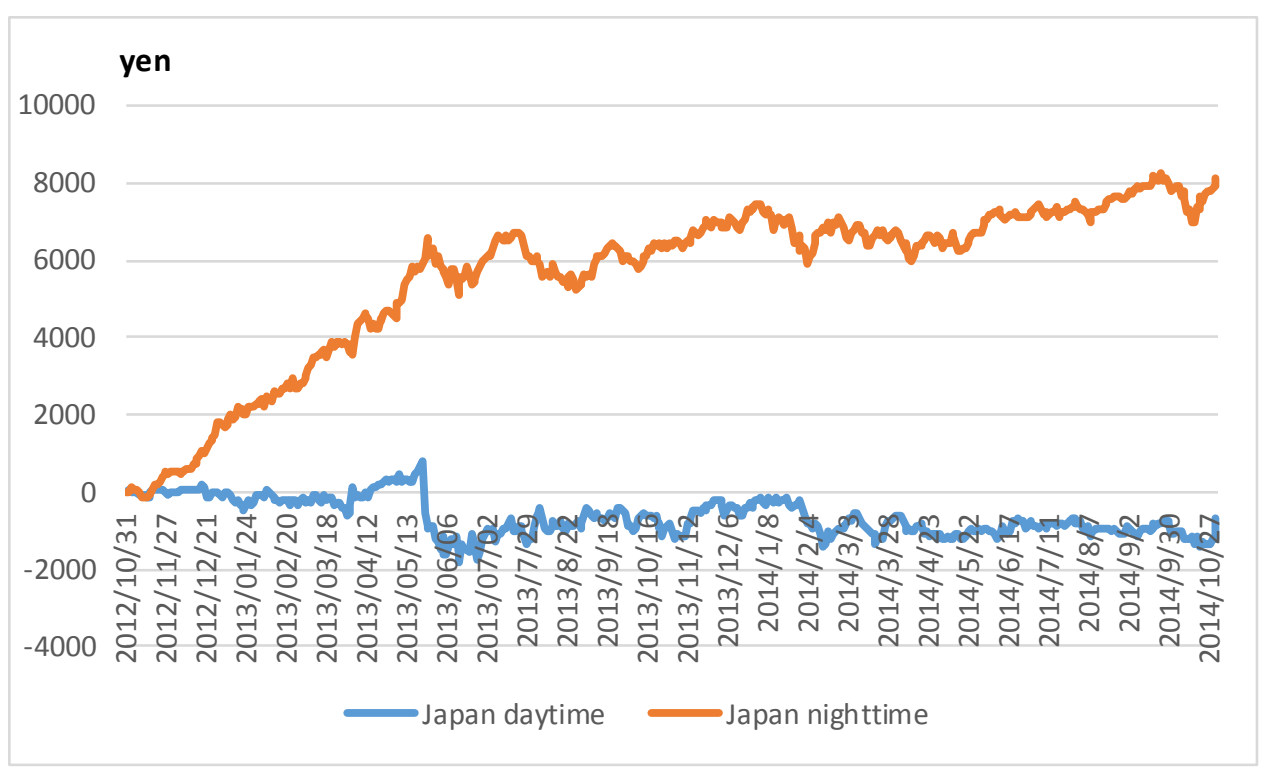

(Sources) Nikkei, Financial Quest and Data Stream. 
Figure 6. Accumulated Changes of the Yen-Dollar Exchange Rates (October 31, $2012=0$ )

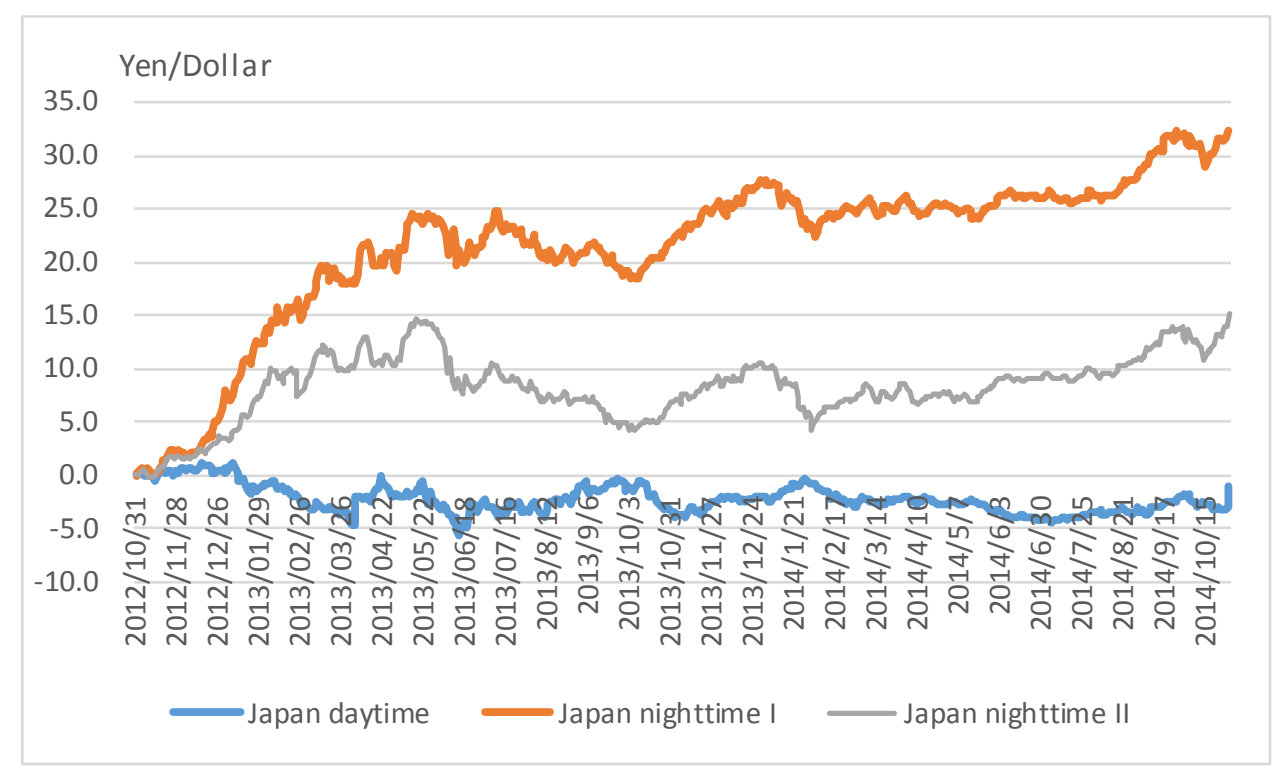

(Source) Nikkei, Financial Quest. 